\section{ECONOMICS}

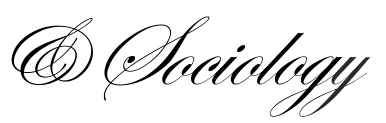

Carvalho, A. O., Ferreira, M. R., \& Silva, P. A. (2019). Partners in a caring society - a nonprofit organization case study. Economics and Sociology, 12(2), 129-146. doi:10.14254/2071-789X.2019/12-2/8

\title{
PARTNERS IN A CARING SOCIETY - A NONPROFIT ORGANIZATION CASE STUDY
}

\begin{abstract}
Amélia O. Carvalho, Porto Polytechnic Institute ESTG-IPP, CIICESI, Portugal E-mail: acarvalho@estg.ipp.pt
\end{abstract}

Marisa R. Ferreira, Porto Polytechnic Institute ESTG-IPP, CIICESI, Portugal E-mail:mferreira@estg.ipp.pt

\author{
Patrícia A. Silva, \\ Porto Polytechnic Institute - \\ ESTG-IPP, CIICESI, Portugal \\ E-mail: \\ pat.alexandra.alves@gmail.com
}

Received: December, 2018

1st Revision: April, 2019

Accepted: May, 2019

DOI: $10.14254 / 2071-$

789X.2019/12-2/8

JEL Classification: M1, M10

\begin{abstract}
In the economic activity of contemporary societies, there is a progressive increase in the importance of nonprofit organizations (NPOs) consequently leading to a growing demand for financial and non-financial information. Considering the mission, values and particular characteristics of NPOs, the accountability reflects a reliable image of their performance for stakeholders. Therefore, NPOs should increasingly give prominence to their accountability. Considering NPOs as mission-based organizations with multiple stakeholders, we believe that the accountability process should be seen specifically as a way of improving the connection between the process and the needs of different stakeholders.

This research intends to perceive accountability, in the third-sector growing context, whether information disclosed improved how they account for their actions to stakeholders and constrained their self-interested behavior. Using a case study of an important Portuguese NPO we intend to give an integrated look on the accountability process, considering the main aspects such as transparency and social responsibility, through such indicators as economic sustainability and social value creation.
\end{abstract}

Keywords: accountability, nonprofit organizations, stakeholders, re-food.

\section{Introduction}

Global trends which arose at the end of the twentieth century as consequences from rapid waste of natural resources, increasing human population, unsatisfied basic needs of people and global destabilization of natural and socioeconomical systems (Płachciak, 2009) led to the creation of many nonprofit organizations. They have several areas of activity, from education to healthcare, culture, social inclusion, and poverty prevention (Weisinger, Borges-Mendez, \& Milofsky, 2016). In the economic activity of contemporary societies, there is a progressive increase in the importance of NPOs, thus leading to a growing demand by different partners and society in general for financial and non-financial information (Costa, Ramus, \& Andreaus, 2011), therefore, NPOs should increasingly give prominence to their accountability (Yasmin, Haniffa, \& Hudaib, 2014). 
Transparency in the accountability process is significant for all involved partners, not only to justify the allocations of money, but also to analyze emotional, ideological, and voluntary commitment (Bargerstock, 2000; Behn, DeVries, \& Lin, 2010; Letts, Ryan, \& Grossman, 1999). Organizations do not need to disclose all information and quantitative data, but they must disclose the interests of different stakeholders so that to strengthen NPO credibility (Balser \& McClusky, 2005). For example, NPOs should present financial (e.g., income statement) (Parsons \& Broadbridge, 2007) and non-financial information (e.g., corporate social responsibility and sustainability reports) (Carman, 2008). They must also provide voluntary disclosure (Parsons \& Broadbridge, 2007; Saxton, Kuo, \& Ho, 2011; Tremblay-Boire \& Prakash, 2015; Zainon, Atan, \& Wah, 2012); therefore, it is important to understand how accountability is performed, what motivates it, and whether it transforms into the expectations the stakeholders are having in this regard.

Our research intends to analyze the influence of organizational accountability through external and internal stakeholders' perceptions. It is not intended to understand just how accountability is done, but rather its influence and implications on those who surround the organization. We also intend to analyze if accountability is providing different levels of information that the stakeholders expect. Different levels of information include satisfaction regarding the level of operability, legitimacy, and social value creation. We will measure economic sustainability and social value creation, because we want to understand, not only the financial dimension, but also the indicators that support the NPO mission, as well as the indicators related to the results of the mission itself.

\section{Literature review}

\subsection{The Accountability Power}

Accountability is the obligation of an individual or organization to account for its activities, to accept responsibility for them, and to disclose the results in a transparent manner (Benjamin \& Campbell, 2014; Eikenberry \& Kluver, 2004). There are various types of accountability, including fiduciary, legal, and professional, as well an obligation to preserve and serve the public good (Balser \& McClusky, 2005). While some types of accountability translate into clear expectations for an organization's activities, for example, filing annual reports, we can also identify a position of responsibility that is exercised in the daily management of internal and external audiences (Parsons \& Broadbridge, 2004).

Considering that NPOs have multiple stakeholders and are mission-based organizations, it can be argued (Benjamin \& Campbell, 2014; Lee \& Nowell, 2015), theoretically, that accountability should be made to these multiple stakeholders. As it is generally not clear who is considered morally and/or legally the most important stakeholder, organizations must develop different accountability systems to meet the needs and expectations of different stakeholders (Harrison, Freeman, \& Abreu, 2015).

The accountability of NPOs should focus on functional and strategic accountability, based on the use of resources, since this use will have an impact on society and other organizations (Petrescu \& Tongel, 2006). Some authors (Brown \& Moore, 2001; Moore, 2000) suggested a new form of NPO accountability: using the strategic relationship between social value, financial performance, and organizational survival. According to Moore's (2000) strategic model, success in NPOs depends on a strategy based on three main points that bind together, the social value creation, economic sustainability, and social responsibility (Moore, 2000). There are other suggestions (Ebrahim, 2003, 2005) that consider that the accountability 
of NPOs should be based on the ethical mission of the organization, considering the type of organization and not restricting itself to rules compliance.

Effective and transparent accountability is a challenge for all organizations as there is a growing concern with reliability and credibility in all sector of activity; these concerns can be a demonstration of organizational effectiveness (Benjamin \& Campbell, 2014). Thus, to promote transparency and increase communication with the various players, there has been a change in the accountability of NPOs, being that disclosure and transparency are essential to maintain trust (Benjamin \& Campbell, 2014; Ebrahim, 2005; Kellner, Townsend, \& Wilkinson, 2016).

This topic has been widely studied both at the level of public and private management, focusing, mainly, on social responsibility, being that NPO accountability has become a symbol of sustainability (Maier, Meyer, \& Steinbereithner, 2016). It is important that organizations are concerned with maintaining transparency and accountability in their actions to ensure the adequacy of agreements, contracts, rules, and potential tax-free access (Felício, Gonçalves, \& Gonçalves, 2013). Accountability must be implemented for moral, ethical, and transparency reasons, hence the importance of accountability to capture the interest of funders, donors, benefactors, participants, and volunteers (Costa et al., 2011). Accountability should demonstrate concern about the social work of NPOs, including care for the poorest and benefits to the less favored (Zhang \& Swanson, 2013). NPOs should be concerned with making their accounts available, not only to regulatory and oversight agents, but to society and in a way that everyone understands (Yasmin et al., 2014). The whole community - possible donors, volunteers, beneficiaries, governments, and society - is interested in accountability because it is a public service. Government and funders want to understand how resources are applied and managed, but with different goals volunteers, donors, and beneficiaries want to provide legitimacy to the organization, making it known and increasing the degree of trustworthiness (Brown \& Moore, 2001). Accountability is important to demonstrate the NPOs' sustainability, (i.e., being financially responsible), but it should always emphasize the social value created (Felício et al., 2013), associating it with the organization's mission and objectives (Moore, 2000).

NPOs must use accountability to demonstrate that its activities are consistent with the values of its mission, thereby responding to stakeholder concerns. In the framework of stakeholder theory the accountability should be interlinked with an approach that prioritizes the management of relationships among the various NPOs' players, seeking to integrate different stakeholders objectives (Friedman \& Miles, 2002). Stakeholder theory proposes three distinct but interrelated approaches: descriptive, instrumental, and normative (Donaldson \& Preston, 1995). The first describes and explains the specific characteristics and behaviors in organizations. The second uses models that examine and link stakeholder management and organizational performance. Finally, the third approach interprets and defines the organization's function through moral and philanthropic principles. Considering these basic relationships, the organization should explore relationships with stakeholders to develop strategies, aiming at commitment and reliability.

\subsection{Accountability and Stakeholders}

NPOs typically work in an intricate environment with multiple stakeholders, such as staff, funders, referral agencies, government officials, volunteers, and clients or participants. NPOs require resources and legitimacy from their stakeholders and these streams are not necessarily predictable or controllable; therefore, stakeholder relationships demand monitoring and managing (Balser \& McClusky, 2005). From the stakeholders' perspective, stakeholders 
evaluate their relationships with NPOs based on how well their expectations are met and how they are treated by the organization (Petrescu \& Tongel, 2006). Receptiveness may be challenging when multiple stakeholder groups have varying, and sometimes conflicting, expectations of the NPO (Balser \& McClusky, 2005). It is absolutely essential for NPOs not merely to answer to their environment, but to be proactive, making decisions to balance responsiveness to stakeholders with their capacity, resources, and beliefs about appropriate activity. It is also essential that organizations publicize the impact they have on the community, to legitimize their projects and obtain funds and thus provide more benefits to the society (Ebrahim, 2005; Kellner et al., 2016). The normative technical commission of AA1000 Stakeholder Engagement Standard (AccoutAbility, 2011) stated that stakeholder engagement was not new; however, it is now understood as fundamental to the organization's sustainability and success. Stakeholder participation can be organized in four different levels (Orduna, 2002): assistance (participation only as a receiver, collaboration (there is an action, but without great commitment), cooperation (participant freely expresses their opinion in the group, revealing a strong sense of belonging), and codecision (stakeholder participates in making the decisionmaking), guaranteeing a democratic position in the group). Thus, NPOs need to find a model of accountability that is a reflection not only of their performance, but also of stakeholder participation. As aggregating and classifying the needs of all stakeholders is not easy, the mission of the NPOs should be used to measure past performance and define future actions (Bryson, Crosby, \& Stone, 2006). Providing financial information is insufficient for an adequate evaluation of the performance, thus the use of non-financial indicators is fundamental and NPOs must consider other dimensions such as economic sustainability and the social value creation (Moore, 2000). These dimensions should be disclosed to stakeholders through indicators included in the different accountability tools (Carvalho, Rodrigues, \& Branco, 2017; Connolly \& Hyndman, 2004) such as the Annual Report as a strategic tool for communicating with stakeholders.

\subsection{Economic Sustainability}

From a social perspective, sustainability is related to a development process that leads to stable growth with equitable income distribution, thus improving the living conditions of the population, and consequently reducing the differences in social levels (Baruch \& Ramalho, 2006). This may be considered a major challenge to NPOs (Salamon, Sokolowski, Haddock, \& Tive, 2012). The greatest importance is placed on the deployment of resources as the ultimate consequence of a strengthened mission, as well as the capacity to establish partnerships highlighting the relevance of articulation between organizations (Costa et al., 2011).

In NPOs, measuring economic sustainability is not restricted to quantitative variables, such as the interpretation of some financial indicators (Baruch \& Ramalho, 2006; Chen \& Hsu, 2013). Profitability can be defined as the benefit provided to society, the number of people assisted, or the improvement of the quality of life (Lovelock \& Weinberg, 1990). Thus, there is no single method for measuring economic sustainability in NPOs, since there are variables that are difficult to quantify. However, these organizations must adopt the best evaluation method according to their purpose and mission (Carvalho, 2005), to mobilize resources, establish partnerships, propose new projects, meet stakeholders expectations, and have autonomy in revenue generation.

In the absence of profit as the main factor of performance evaluation, NPOs should focus on creating a budget balance and on controlling its resources (Drucker, 1999). Thus, NPO sustainability is also a function of the degree of social "rooting", the capacity for local 
articulation, and the credibility built within the society (Baruch \& Ramalho, 2006; Zhang \& Swanson, 2013).

In our research, the following indicators will be analyzed to measure the economic sustainability dimension: (a) the relationship between expenditure and revenue, (b) subsidies, (c) donations, (d) partnerships, and (e) number of beneficiaries. The chosen indicators are based on the model defended by Carvalho (2005). The aim is to study the financial sustainability component, observing the success in controlling expenditures, the effectiveness in attracting resources, and the satisfaction of donors and funders, as well as their reflection on the overall performance of the organization. The use of this model (Carvalho, 2005) appeared to be the most appropriate given the specificity of NPOs, where the control process and the analysis mechanisms require that besides the mission, other variables, such as history, organizational culture, organizational structure, services provided, quality, and dynamics of management, partners, as well as stakeholders expectations, among others, are considered for the decisionmaking process.

\subsection{Social Value Creation}

The long-term survival of organizations is based on the ability to maximize the social value created as defined in the organization's mission and as understood by multiple stakeholders (Felício et al., 2013). By focusing on the mission, combining vision and values, the organization intends to create social value, which also contributes to economic sustainability. Economic sustainability is a means to achieve an end, (i.e., being economically and financially responsible is a condition to be respected), but it is still an instrument to maximize social value as defined in an NPO mission (Balser \& McClusky, 2005). There are even broader perspectives on the valuation of the social value created, in which all stakeholders are included as they are relevant to the NPO and to the community (Freeman, 1984). The focus on social value creation is an important part of NPO development, and some have done this by building social networks with their stakeholders (Felício et al., 2013). The creation of social value refers to the social value produced according to the NPO mission; practices are developed to benefit communities, develop social actions, reduce social exclusion, and transform people's lives (Moore, 2000).

Though it is difficult to measure the concept of social value, it is possible to use some indicators that eventually point to the degree of social entrepreneurship in the sense of generating social value - the development of social action is the main indicator (Chen \& Hsu, 2013; Costa et al., 2011; Moore, 2000). Consequently, the improvement of social conditions and/or the transformation of social reality contribute to social value creation. Social value creation of NPOs has a multidimensional format and involves social and financial indicators, as well as social improvements or transformation of social reality (Costa et al., 2011; Felício et al., 2013). To measure the creation of social value, also based on the model of Carvalho (2005) and the mission of the organization, we will evaluate indicators related to the means necessary to carry out the mission as well as indicators related to the results of the mission itself and the evolution of the organization, such as: (a) the evolution of the number of volunteers, (b) the statistics on the service provided (number of meals served), (c) the increase of centers at the national level, and (d) the involvement of stakeholders in the mission and (e) the evaluation of the social value created. In this sense, performance corresponds to the potential of value creation. Performance does not exist by itself, it is built by stakeholders through a continuous process and is strictly linked to the variables that contribute to achieve the NPOs objectives (Pavão \& Rossetto, 2015). The collective construction of answers, regarding the participatory process, is based on two essential points: self-promotion and citizenship (Demo, 1988). In 
democracy, the individual is understood in a context of social relations, and with the multiple roles they may play volunteer, beneficiary, manager, etc. (Abdi \& Shultz, 2013).

\section{Methodological approach}

In our research, we used a specific NPO as the unit for our case study - Re-food. Refood is an independent, citizen driven, 100\% volunteer, eco-humanitarian community charity, working to eliminate food waste and hunger on a neighborhood basis. As illustrated in Figure 1, Re-food collects leftovers from cafes and restaurants and distributes to those who do not have enough food. Re-food operates in and for the community, working without salaries and avoiding all costs or investments that do not serve its mission. Its low cost and high productivity model improve the quality of life of people in need while strengthening the social fabric of the local community. Its mission is eliminating food waste and ending hunger, involving the full community in a common cause. Re-food wants a new world, where everyone has the food that they need, where all the food produced goes first to feed people, where citizens participate actively in the management of community resources, and where everyone assumes his or her power, right, and obligation to transform the world into a better place. Its values are linked with equality, respect, inclusion, sustainability and optimism.

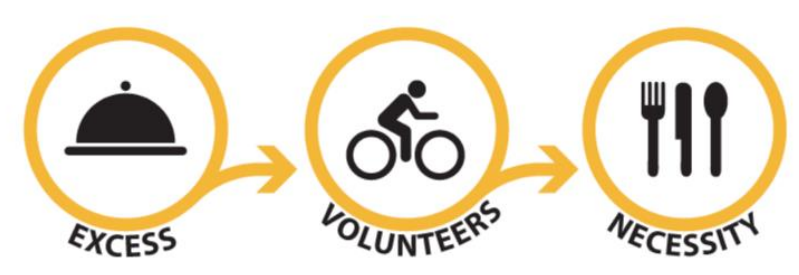

Figure 1. Re-food movement

Source: www.re-food.org

The empirical research was developed through interviews and documental analysis. Interviews were conducted with 12 stakeholders based on the four different levels previously mentioned (Orduna, 2002): assistance, collaboration, cooperation, and codecision (see Appendix 1 and 2). When documental analysis is used it is fundamental to know the NPO, its way of acting, and what type of information it makes available. We did a technical analysis to verify the existence (or not) of important information, considering the objectives previously defined. The aim of our research was to collect data that allowed us to evaluate the organization in different components and dimensions (economic sustainability and creation of social value), comparing data from different years. Table 1 and Table 2 present all the considered variables belonging to each dimension. 
Table 1. Dimensions of analysis

- How do NPOs incentivize stakeholders' participation? (AccoutAbility, 2011)

- What indicators are considered most adequate to evaluate the organization's performance? (Carvalho, 2005)

Economic Sustainability - Considering the following indicators, please indicate if they appear appropriate and why: (a) relationship between expenditure and revenue; (b) subsidies; (c) donations; (d) partnerships; and (e) number of beneficiaries.

- Do you consider there to be a greater availability of resources when organizations provide more information to stakeholders? (Parsons \& Broadbridge, 2004)

- Does stakeholder participation allow the collective construction of responses to institutional challenges? If yes, please explain how these answers are constructed. (Mendes, 2007)

Social Value Creation

- Stakeholders' participation is mostly active or passive? (Orduna, 2002)

- To what extent does stakeholder engagement improve or undermine organizational performance? (Mendes, 2007)

- Generally, do you consider that the NPOs defined objectives are reached? (Barney, 1991)

The documental analysis (Table 2) was conducted by examining the general activities data found in the organization's website, the annual report, and the financial report.'

Table 2. Documental Analysis

\begin{tabular}{|c|c|c|c|c|}
\hline & & Website & Annual Report & Financial Report \\
\hline \multirow{6}{*}{ General data } & Organization background & $\mathrm{x}$ & $\mathrm{x}$ & \\
\hline & Mission & $\mathrm{x}$ & $\mathrm{x}$ & \\
\hline & Evolution & $\mathrm{x}$ & $\mathrm{x}$ & \\
\hline & Structure & $\mathrm{x}$ & $\mathrm{x}$ & \\
\hline & Team & $\mathrm{x}$ & $\mathrm{x}$ & \\
\hline & Financial results & & & $\mathrm{x}$ \\
\hline \multirow{6}{*}{$\begin{array}{c}\text { Economic } \\
\text { Sustainability }\end{array}$} & Expenses & & $\mathrm{x}$ & $\mathrm{x}$ \\
\hline & Revenues & & $\mathrm{x}$ & $\mathrm{x}$ \\
\hline & Donations & & $\mathrm{x}$ & $\mathrm{x}$ \\
\hline & Subsidies & & $\mathrm{x}$ & $\mathrm{x}$ \\
\hline & Partnerships & & $\mathrm{x}$ & $\mathrm{x}$ \\
\hline & Beneficiaries & & & $\mathrm{x}$ \\
\hline \multirow{4}{*}{$\begin{array}{l}\text { Social Value } \\
\text { Creation }\end{array}$} & Mission & $\mathrm{x}$ & & \\
\hline & Volunteers & $\mathrm{x}$ & & $\mathrm{x}$ \\
\hline & Distributed meals & & $\mathrm{x}$ & $\mathrm{x}$ \\
\hline & Stakeholder's engagement & & & $X$ \\
\hline
\end{tabular}

An extensive and intensive documentary analysis was proceeding in order to support the referred dimensions: economic sustainability and social creation value. Both dimensions are presented in the annual report and financial report, this information is disclosed forward in those reports but not directly disclosed in the website for all the interested stakeholders, so this must be looked a transparency issue. 


\section{Results and discussion}

In our research, we analyzed the importance of accountability to the stakeholders of Refood, its influence on the relationship, and their acknowledgment and acceptance to the organization. This influence was studied based on general data about the organization as well as the two dimensions of economic sustainability and the creation of social value.

After the formulation of a starting question, the literature review, the analysis of data and the answers of the interviews, we concluded that while accountability, (i.e., results and information availability) is imperative, it is not considered by the stakeholders to be the most important factor. Instead, the organization's mission was the central aspect highlighted by stakeholders. Encouraging stakeholders to participate in the organization's activities, and even being part of the management team, makes the organization more inclusive as well a credible image. The dissemination and growth of a specific project involves being closer to the community to capture different resources, which implies a very direct and personal communication both in the community and inside the organization (Parsons \& Broadbridge, 2004). Re-food has a local operation in many districts, but also the first and largest organization on national coverage, and intends to be very close to the community, in order to attract the largest number of people to the project as possible. It has a very close link to the stakeholders, leading to a detailed knowledge about them, allowing a very inclusive shape of actions and procedures, managing to help people from different areas. Stakeholders are called to participate in Re-food's daily activities and may gain some visibility since the project itself is quite laudable. This joint and daily work for the fulfilment of the mission increases the creation of social value. Re-food activities aim to change social reality and provide improvements in the standard of living of disadvantaged people. By analyzing the various documents published by Re-food, we can see that the involvement of different stakeholders occurs not only in their daily work and in the mission pursuit, but also in the evaluation of their work and in the construction of a better future. Stakeholders have the opportunity to be heard and participate in the decisionmaking processes.

It is generally agreed that information disclosure must be wide-ranging, and therefore NPOs should present financial (e.g., income statement) and non-financial information (e.g., corporate social responsibility, sustainability) (Carman, 2008). It is the availability of information on different indicators that motivates stakeholders' participation, making the fulfillment of mission and attracting more and more resources, providing the potential for the economic sustainability of the NPO.

The main reason for the existence of an NPO is their specific mission, which should be their strategic attraction to stakeholders but considering the specific mission of each NPO (Andrade \& Franco, 2007). Encouraging participation fosters the development of trust and transparent dialogue. The dissemination of different procedures and practices creates standardization which informs and influences the stakeholders in improving their own practices. This process is reproduced in the organization and ultimately, in society (AccountAbility, 2011).

At Re-food, while there is a long way to go in terms of disclosure, we can see their effort and focus in the continuing improvement of management tools which are fostering a more diversified, real, and transparent accountability. The operationalization of Re-food's mission has been a success, but it is necessary to convey this same success to communicating its accountability, to present Re-food's activities more rigorously. This improvement will certainly capture more financial and human resources which are indispensable to their work.

It was verified in the literature review that the economic sustainability of an NPO is perceptible through the analysis of a set of factors, both economic and social. Factors such as 
information on resource efficiency, financial stability, the organization's reputation, and the organization's mission and beneficiaries can affect the volume of donations received by the NPO as this is useful information to donors (Parsons \& Broadbridge, 2004, 2007).

This was confirmed at Re-food: as the project became more widely known, at the local level through awareness-raising activities and at the national level through newspapers and television, there was an increase in donations, both in products and cash. Re-food has gone from an unknown local project to an exponentially growing movement. The increase in the number of nuclei at the national level and, as illustrated in Table 3, the corresponding increase in beneficiaries, and consequently, the reduction of food waste leads to an increase in the demand from partners and food sources that are associated with the organization. The Internet, especially Facebook, has proven to be very effective in publicizing the project and in attracting other resources such as volunteers, which are necessary for the project to function properly. Facebook can be considered as a new pathway to attract and engage volunteers, as we can see in Figure 2 and Figure 3 (see appendix 3). Re-food regularly uses images to mobilize the community. In Figure 2, we can see an important amount of food surplus that was redistributed and reused, and in Figure 3 we see an appeal to volunteers to join the organization. Re-food has been growing since its early days, quantitatively and qualitatively (see Table 3). It grows as citizens decide to intervene in their own community and it improves as its members discover better ways to accomplish the mission and serve their communities. The documental analysis illustrates that all the economic sustainability measures have improved in the considered period (see appendix 4).

Table 3. Economic sustainability measures

\begin{tabular}{lcccc}
\hline & 2011 & 2012 & 2013 & 2014 \\
\hline Expenses higher than revenue & $\uparrow$ & $\uparrow$ & $\uparrow$ & $\uparrow$ \\
\hline Subsidies & $\uparrow$ & $\uparrow$ & $\uparrow$ & $\uparrow$ \\
\hline Donations & $\uparrow$ & $\uparrow$ & $\uparrow$ & $\uparrow$ \\
\hline Number of partnerships & $\uparrow$ & $\uparrow$ & $\uparrow$ & $\uparrow$ \\
\hline Number of beneficiaries & $\uparrow$ & $\uparrow$ & $\uparrow$ & $\uparrow$ \\
\hline
\end{tabular}

Legend: $\uparrow$ increasing; $\downarrow$ decreasing; $\rightarrow$ neutral

The use of local resources and the efficient management of them, allows Re-food to create a cohesive network that reduces hunger and simultaneously food waste. This contributes to the happiness and personal fulfilment of those who volunteer for the organization, thus enhancing the creation of social value. All this information about NPOs is very important to their continuity, and the evaluation of results is closely linked to economic sustainability (Fischer \& Falconer, 2001; Parsons \& Broadbridge, 2004).

At Re-food there is a constant evaluation of the work developed, there is a constant search for better ways of using resources, for an ever increasing collect of donations and subsidies, but always in a balanced and sustainable way, as suggest by Devaro \& Brookshire (2007) the efficiency is related to the degree to which the organization directs its resources to the organization's mission. The efficiency growth also goes through good practices, hence the conception of manuals which allow uniform and coherent work at the national level. It should be noted that economic sustainability is also achieved through voluntary work, and their work evolves the organization. In fact, volunteers make up the workforce of Re-food which is the greatest contribution to its economic sustainability as it is unpaid work.

Volunteers are often very effective because they work with their willingness (Fallon \& Rice, 2011; Macduff, Netting, \& O'Connor, 2009). The positive interaction of many different 
volunteers from diverse generations produces an atmosphere of cooperation and goodwill that allows Re-food's work to be carried out. Knowing that the participative involvement of the stakeholders in the organization brings advantages and disadvantages, Re-food believes that greater stakeholder involvement may lead to less conflict and higher collective responsibility, thus increasing the possibility of achieving objectives and making the project more solidary and improving the organization's performance. As illustrated earlier, in Table 2, the creation of social value is proven, among other elements, by the positive effects on volunteers and in the community at large. As the organization model is simple and inclusive, this may guarantee human sustainability and the exponential growth of the Re-food movement.

We have the evidence from the documental analysis (see appendix 4) that the social value measures (see Table 4) was improved, we have witnessed a significant increase in the components of the two dimensions over the years, specifically during the considered period.

NPOs need resources beyond those destined exclusively to the beneficiaries to meet the costs of operationalization (Bargerstock, 2000). Re-food needs a permanent supply of a variety of goods to ensure the action of the operation centers, from rubbish bags to kitchen paper, among others. It is possible to ensure the stock of such goods through donations from individuals, volunteers, and partnerships with companies and other organizations.

Table 4. Measures of Social Value Creation

\begin{tabular}{lcccc}
\hline & $\mathbf{2 0 1 1}$ & $\mathbf{2 0 1 2}$ & $\mathbf{2 0 1 3}$ & $\mathbf{2 0 1 4}$ \\
\hline Number of volunteers & $\uparrow$ & $\uparrow$ & $\uparrow$ & $\uparrow$ \\
\hline Number of distributed meals & $\uparrow$ & $\uparrow$ & $\uparrow$ & $\uparrow$ \\
\hline Number of nuclei (subsidiaries) & $\uparrow$ & $\uparrow$ & $\uparrow$ & $\uparrow$ \\
\hline Number of food sources & $\uparrow$ & $\uparrow$ & $\uparrow$ & $\uparrow$ \\
\hline
\end{tabular}

Legend: $\uparrow$ increasing; $\downarrow$ decreasing; $\rightarrow$ neutral

The unconditional support of several municipal councils that, in most of the nuclei, ensure the payment of water and electricity. The partnership with Portugal Telecom allows free telephone and internet access in all operations centers. This support is fundamental. Donors are more willing to make contributions to efficient organizations and service partnerships allow Re-food to build an image that attracts more resource. Consequently, organizations better known by the best services will be able to attract more resources (Parsons \& Broadbridge, 2004).

This work is demanding and is only possible with the engagement of the stakeholders. The obstacles that may arise are overcome over time, with a more active participation of stakeholders, increasing the right to participate in decision-making, considering that sharing decisions and responsibilities with stakeholders, making them more active, more critical and committed with the organization mission may bring positive impacts (Hsieh, Curtis, \& Smith, 2008) since it is the collective construction of responses by the different stakeholders that allows the project to grow, allows the capture of more resources for the promotion of economic sustainability and the creation of social value. Accountability improve the organization in different dimensions, like thorough credibility and transparency. Thus, based on the study carried out on Re-food, it cannot be confirmed that accountability influences the relationship with stakeholders. However, the information provided on the website that defined the year 2016 as the year of transparency, illustrates an attempt to improve accountability and to draw the attention of stakeholders to its importance. For stakeholders, the pursuit of Re-food's mission is central, and it drives the pursuit of more resources and the commitment to the project. 


\section{Conclusion}

The increasing visibility and attention to NPOs led to the emergence of methodologies and tools specifically designed to analyze and support the action of these organizations. Accountability is a recent example of such methodologies, involving and motivating diverse stakeholders, encouraging them to participate and to become involved in the organization's activity and decision-making. Accountability must respond to what stakeholders want to know and should be an evaluation tool for the organization itself. Accountability should be a clear management tool, reflecting the fulfilment of the objectives and the scope of the organization's mission.

Considering our research unit, Re-food, we can underline the importance of its mission, which by rescuing food waste, helps to reduce hunger and at the same time protects the environment, providing well-being and creating social value. The main difficulties were also identified - fundraising, volunteers, and sustainability. It is essential to standardize procedures, to attract an increasing number of volunteers, to motivate them, and to ensure project sustainability. The question of sustainability must be considered in the long run; the actions developed by the organizations must be based on the future objectives and not only on their immediate effect. Sustainability should be based on an efficient management of resources, ensuring the flow of new resources but also optimizing the existing ones. This is necessary to increase the effectiveness of the organization's intervention, increase the number of partnerships, and therefore obtaining alternative sources of financial resources. In our research, we also recognized the position of volunteering as an essential condition for the organization's survival and economic sustainability. Volunteer recruitment is not a simple process, and proper management of all processes involving volunteers is required. Volunteers must realize what their roles are and feel his/her importance to the project, thus deepening his/her commitment to the organization.

Our empirical analysis allowed the corroboration of the theoretical relations exposed in our general objective. Based on our data analysis and discussion it can be pointed out that the results obtained through the documentary analysis and interviews corroborate our literature review, however we don't have a large established body of literature to support totally our research without limitations. In the case of Re-food, the exponential growth of the organization has been made quickly and almost automatically, and therefore, economic sustainability and accountability were not part of the immediate worries or policies. The first directives of procedure standardization at the national level have emerged, as well as the commitment to an efficient and more transparent accountability.

\section{Limitations and future research}

Our research presents some limitations, both in terms of the NPO size and the form of accountability, since it has been organized around a small number of questions, specifically designed to our research.

Furthermore, our study is limited to the Re-food case that, though portray a central problem and an international concern for any NPO where the excess, the volunteers and the necessity are a tough reality and concern issue. Recognizing our research limitations, it is pertinent in future research to broaden the scope of analysis to a larger number of organizations. Another limitation of this research is that we considered only the direct stakeholders and we don't have analyzed the point of view of other important stakeholders like the State as a central support. We have analyzed two critical dimensions for this NPO, but there are other dimensions that also deserve a greater research effort, e.g., the innovation practices and their relationship with 
transparency. The future path also includes the adaptation of long-term measures, and specific objectives grounded on economic sustainability. All these topics will be the focus of future research and would allow us to expand the present work and complement the previous empirical evidences.

\section{References}

Abdi, A. A., \& Shultz, L. (2013). Citizenship and Youth Social Engagement in Canada: Learning Challenges and Possibilities. Journal of Education, 1(2), 54-74.

AccoutAbility. (2011). AA1000 Stakeholder Engagement Standard (2011). In AccountAbility. London, UK.

Andrade, A. M., \& Franco, R. C. (2007). Economia do Conhecimento e Organizações sem Fins Lucrativos (S. P. I. - S. P. de Inovação, Ed.). Porto: Princípia Editora.

Balser, D., \& McClusky, J. (2005). Managing stakeholder relationships and nonprofit organization effectiveness. Nonprofit Management \& Leadership, 15(3), 295-315. https://doi.org/10.1002/nml.70

Bargerstock, A. S. (2000). The HRM Effectiveness Audit: a Tool for Managing Accountability in HRM. Public Personnel Management, 29(4), 517-526.

Barney, J. (1991). Firm resources and sustained competitive advantage. Journal of Management, 17(1), 99-120.

Baruch, Y., \& Ramalho, N. (2006). Communalities and Distinctions in the Measurement of Organizational Performance and Effectiveness Across For-Profit and Nonprofit Sectors. Nonprofit And Voluntary Sector Quarterly, 35(1), 39-65. https://doi.org/10.1177/0899764005282468

Behn, B. K., DeVries, D. D., \& Lin, J. (2010). The determinants of transparency in nonprofit organizations: An exploratory study. Advances in Accounting, 26(1), 6-12.

Benjamin, L. M., \& Campbell, D. C. (2014). Nonprofit Performance: Accounting for the Agency of Clients. Nonprofit and Voluntary Sector Quarterly, 1-19. https://doi.org/10.1177/0899764014551987

Brown, L. D., \& Moore, M. H. (2001). Accountability, Strategy, and International Nongovernmental Organizations. Nonprofit and Voluntary Sector Quarterly, 30(3), 569587.

Bryson, J. M., Crosby, B. C., \& Stone, M. M. (2006). The Design and Implementation of CrossSector Collaboration: Propositions from the Literature Abstract. Public Adminstration Review, 66(December), 17-18. https://doi.org/10.1111/j.1540-6210.2006.00665.x

Carman, J. G. (2008). Nonprofits, Funders, and Evaluation: Accountability in Action. The American Review of Public Administration, 39(4), 374-390. https://doi.org/10.1177/0275074008320190

Carvalho. (2005). Organizações Não Lucrativas. Lisboa: Sílabo.

Carvalho, A. O., Rodrigues, L. L., \& Branco, M. C. (2017). Factors Influencing Voluntary Disclosure in the Annual Reports of Portuguese Foundations. In Voluntas (Vol. 28). https://doi.org/10.1007/s11266-017-9883-8

Chen, H. L., \& Hsu, C.-H. (2013). Entrepreneurial orientation and firm performance in nonprofit service organizations: contingent effect of market orientation. The Service Industries Journal, 33(5), 445-466. https://doi.org/10.1080/02642069.2011.622372

Connolly, C., \& Hyndman, N. (2004). Performance Reporting: A Comparative Study of British and Irish Charities. The British Accounting Review, 36, 127-154. https://doi.org/10.1016/j.bar.2003.10.004

Costa, E., Ramus, T., \& Andreaus, M. (2011). Accountability as a Managerial Tool in Non- 
Profit Organizations: Evidence from Italian CSVs. Voluntas, 22(3), 470-493. https://doi.org/10.1007/s11266-011-9183-7

Demo, P. (1988). Participação é Conquista (Cortez Edi). São Paulo - Brasil.

Donaldson, T., \& Preston, L. (1995). The Stakeholder Theory of the Corporation: Concepts, Evidence, and Implications. The Academy of Management Review, 20(1), 65-91.

Drucker, P. F. (1999). Management Challenges for the 21st Century. New York: Harper Collins.

Ebrahim, A. (2003). Accountability In Practice: Mechanisms for NGOs. World Development, 31(5), 813-829. https://doi.org/https://doi.org/10.1016/S0305-750X(03)00014-7

Ebrahim, A. (2005). Accountability Myopia: Losing Sight of Organizational Learning. Nonprofit and Voluntary Sector Quarterly, 34(1), 56-87. https://doi.org/10.1177/0899764004269430

Eikenberry, A. M., \& Kluver, J. D. (2004). The Marketization of the Nonprofit Sector : Civil Society at Risk? Public Administration Review, 64(2), 132-140.

Fallon, B. J., \& Rice, S. M. (2011). Investment in staff development within an emergency services organisation: comparing future intention of volunteers and paid employees. The International Journal of Human Resource Management, (March 2013), 1-16. https://doi.org/10.1080/09585192.2011.561222

Felício, J. A., Gonçalves, H. M., \& Gonçalves, V. da C. (2013). Social value and organizational performance in non-profit social organizations: Social entrepreneurship, leadership, and socioeconomic context effects. Journal of Business Research, 66(10), 2139-2146. https://doi.org/10.1016/j.jbusres.2013.02.040

Fischer, R. M., \& Falconer, A. P. (2001). Voluntariado empresarial - estratégias de empresas no brasil. Revista de Administração, 36(3), 15-27.

Freeman, R. E. (1984). Strategic Management: A Stakholder Approach. In Journal of Management Studies (Vol. 29). https://doi.org/10.1017/CBO9781139192675

Friedman, A., \& Miles, S. (2002). Developing Stakeholder Theory. Journal of Management Studies, 39(1), 1-21.

Harrison, J. S., Freeman, R. E., \& Abreu, M. C. S. de. (2015). Stakeholder Theory As an Ethical Approach to Effective Management: Applying the theory to multiple contexts. Revista Brasileira de Gestão de Negócios, 17(55), 858. https://doi.org/10.7819/rbgn.v17i55.2647

Hsieh, J., Curtis, K. P., \& Smith, A. W. (2008). Implications of stakeholder concept and market orientation in the US nonprofit arts context. International Review on Public and Nonprofit Marketing, 5(1), 1-13.

Kellner, A., Townsend, K., \& Wilkinson, A. (2016). 'The mission or the margin?' A highperformance work system in a non-profit organisation. The International Journal of Human Resource Management, 5192(June), 1-22. https://doi.org/10.1080/09585192.2015.1129636

Lee, \& Nowell, B. (2015). A Framework for Assessing the Performance of Nonprofit Organizations. American Journal of Evaluation, 36(3), 299-319. https://doi.org/10.1177/1098214014545828

Letts, C. W., Ryan, W. P., \& Grossman, A. (1999). High performance nonprofit organizations: Managing upstream for greater impact. New York: John Wiley.

Lovelock, C., \& Weinberg, C. (1990). Public and Nonprofit Marketing. Course Technology.

Macduff, N., Netting, F. E., \& O'Connor, M. K. (2009). Multiple Ways of Coordinating Volunteers With Differing Styles of Service. Journal of Community Practice, 17(4), 400423. https://doi.org/10.1080/10705420903300488

Maier, F., Meyer, M., \& Steinbereithner, M. (2016). Nonprofit Organizations Becoming Business-Like: A Systematic Review. Nonprofit and Voluntary Sector Quarterly, 45(1), 
64-86.

Mendes, I. D. P. (2007). A dimensão participativa dos cursos de Educação e Formação de Adultos (EFA) no Vale do Ave, norte de Portugal. Universidade de Granada, Granada, Espanha.

Moore, M. H. (2000). Managing for Value: Organizational Strategy in For-Profit , Nonprofit, and Governmental Organizations. Nonprofit and Voluntary Sector Quarterly, 29(1), 183 204.

Orduna, M. G. (2002). Una aproximación a la educación para a participación social en tercero sector. In Naval Durán - Concepción - participar en la sociedad civil. Navarra EUNSA.

Parsons, E., \& Broadbridge, A. (2004). Managing Change in Nonprofit Organizations: Insights from the UK Charity Retail Sector. VOLUNTAS: International Journal of Voluntary and Nonprofit Organizations, 15(3), 227-242. https://doi.org/10.1023/B:VOLU.0000046279.46964.b5

Parsons, E., \& Broadbridge, A. (2007). Charity, retail or care? Gender and managerialism in the charity retail sector. Women in Management Review, 22(7), 552-567.

Pavão, Y. M. P., \& Rossetto, C. R. (2015). Stakeholder management capability and performance in Brazilian cooperatives. Revista Brasileira de Gestao de Negocios, 17(55), 870-889. https://doi.org/10.7819/rbgn.v17i55.2125

Petrescu, C., \& Tongel, M. (2006). Views from the Outside: How the Nonprofit Community Characterizes High Performance Nonprofit Organizations. Transylvanian Review of Administrative Sciences, 18(E/October), 96-107.

Płachciak, A. (2009). Sustainable development - The way of building just society. Economics and Sociology, 2(1), 105-110. https://doi.org/10.14254/2071-789X.2009/2-1/10

Salamon, L. M., Sokolowski, S. W., Haddock, M., \& Tive, H. S. (2012). Portugal's Nonprofit Sector in Comparative Context. Johns Hopkins Center for Civil Society Studies.

Saxton, G. D., Kuo, J.-S., \& Ho, Y.-C. (2011). The Determinants of Voluntary Financial Disclosure by Nonprofit Organizations. Nonprofit and Voluntary Sector Quarterly, 41(6), 1051-1071.

Tremblay-Boire, J., \& Prakash, A. (2015). Accountability.org: Online Disclosures by U.S. Nonprofits. VOLUNTAS: International Journal of Voluntary and Nonprofit Organizations, 26(2), 693-719.

Weisinger, J. Y., Borges-Mendez, R., \& Milofsky, C. (2016). Diversity in the Nonprofit and Voluntary Sector. Nonprofit and Voluntary Sector Quarterly, 45(IS), 3S-27S. https://doi.org/10.1177/0899764015613568

Yasmin, S., Haniffa, R., \& Hudaib, M. (2014). Communicated Accountability by Faith-Based Charity Organisations. Journal of Business Ethics, 122(1), 103-123. https://doi.org/10.1007/s10551-013-1759-2

Zainon, S., Atan, R., \& Wah, Y. B. (2012). Applying Stakeholder Approach in Developing Charity Disclosure Index. Archives Des Sciences, 65(5), 204-229.

Zhang, D. Di, \& Swanson, L. A. (2013). Social Entrepreneurship in Nonprofit Organizations: An Empirical Investigation of the Synergy Between Social and Business Objectives. Journal of Nonprofit \& Public Sector Marketing, 25(1), 105-125. https://doi.org/10.1080/10495142.2013.759822 


\section{Appendix 1. Levels of stakeholder participation}

\begin{tabular}{|c|c|c|c|c|}
\hline Levels & Internal & Justification & External & Purpose \\
\hline \multirow[t]{2}{*}{ Assistance } & & & Beneficiary & $\begin{array}{l}\text { Receive food surplus; } \\
\text { comply with the rules and } \\
\text { operating procedures }\end{array}$ \\
\hline & & & $\begin{array}{l}\text { Suppliers: electricity, } \\
\text { telecommunications, } \\
\text { insurance }\end{array}$ & $\begin{array}{l}\text { Sell their products or } \\
\text { services as requested by the } \\
\text { organization }\end{array}$ \\
\hline \multirow[t]{2}{*}{ Collaboration } & & & $\begin{array}{l}\text { Suppliers (food): } \\
\text { supermarkets, bakeries, } \\
\text { restaurants, fruit shops }\end{array}$ & $\begin{array}{l}\text { They donate the food } \\
\text { surplus and all kinds of } \\
\text { materials to the operations } \\
\text { center }\end{array}$ \\
\hline & & & $\begin{array}{l}\text { Partnerships: official } \\
\text { organizations, public } \\
\text { organizations (like } \\
\text { municipalities or social } \\
\text { security), parish, tv } \\
\text { channels, charities, private } \\
\text { university }\end{array}$ & $\begin{array}{l}\text { Exchange of good practice } \\
\text { information, inter- } \\
\text { organizational partnerships, } \\
\text { referral of beneficiaries }\end{array}$ \\
\hline \multirow[t]{3}{*}{ Cooperation } & Managers & $\begin{array}{l}\text { They manage the } \\
\text { operation of the different } \\
\text { shifts; articulate } \\
\text { information between } \\
\text { coordinators and } \\
\text { volunteers; participate in } \\
\text { activities developed as } \\
\text { volunteers }\end{array}$ & Volunteers & $\begin{array}{l}\text { Ensure the operation of the } \\
\text { organization either in the } \\
\text { collection, storage or } \\
\text { distribution of the food } \\
\text { surplus collected; publicize } \\
\text { the project in the } \\
\text { community; collaborate in } \\
\text { the accomplishment of } \\
\text { activities }\end{array}$ \\
\hline & & & Community & $\begin{array}{l}\text { Supports the activities } \\
\text { developed by the } \\
\text { organization; creates and } \\
\text { builds the image of the } \\
\text { organization and public } \\
\text { opinion }\end{array}$ \\
\hline & & & Donors & $\begin{array}{l}\text { Support the organization } \\
\text { operation by donating } \\
\text { goods and / or money }\end{array}$ \\
\hline \multirow[t]{3}{*}{ Codecision } & President & $\begin{array}{l}\text { Outlines objectives; } \\
\text { proposes activities; meets } \\
\text { periodically with the } \\
\text { board and nuclei } \\
\text { coordinators }\end{array}$ & Managers - Volunteers & $\begin{array}{l}\text { Manage shifts, distribute } \\
\text { tasks, coordinate with the } \\
\text { volunteers the distribution } \\
\text { of food, establish contact } \\
\text { with the beneficiaries on a } \\
\text { daily basis }\end{array}$ \\
\hline & Board & $\begin{array}{l}\text { Jointly with the president } \\
\text { define goals and } \\
\text { procedures, establish } \\
\text { communication with } \\
\text { different nuclei and } \\
\text { partners }\end{array}$ & & \\
\hline & Coordinators & $\begin{array}{l}\text { They meet monthly and } \\
\text { define procedures based } \\
\text { on decisions of the board }\end{array}$ & & \\
\hline
\end{tabular}


Appendix 2. Internal and external stakeholders interviewed

\begin{tabular}{lccl}
\hline Levels & Internal & External & Stakeholders \\
\hline Assistance & & $\mathrm{x}$ & Beneficiary \\
& $\mathrm{x}$ & Suppliers \\
\hline Collaboration & $\mathrm{x}$ & Suppliers (food) \\
& $\mathrm{x}$ & Partnerships \\
\hline Cooperation & $\mathrm{x}$ & Volunteers \\
& $\mathrm{x}$ & Community \\
& & $\mathrm{x}$ & Donors \\
& $\mathrm{x}$ & & Managers \\
\hline Codecision & $\mathrm{x}$ & Managers - Volunteers \\
& $\mathrm{x}$ & & President \\
& $\mathrm{x}$ & & Coordinators \\
\hline
\end{tabular}


Appendix 3. Facebook posts

In this appendix we present two figures to support the practical evidence of Re-food mission.

Figure 2. Surplus collected at the end of an important football game

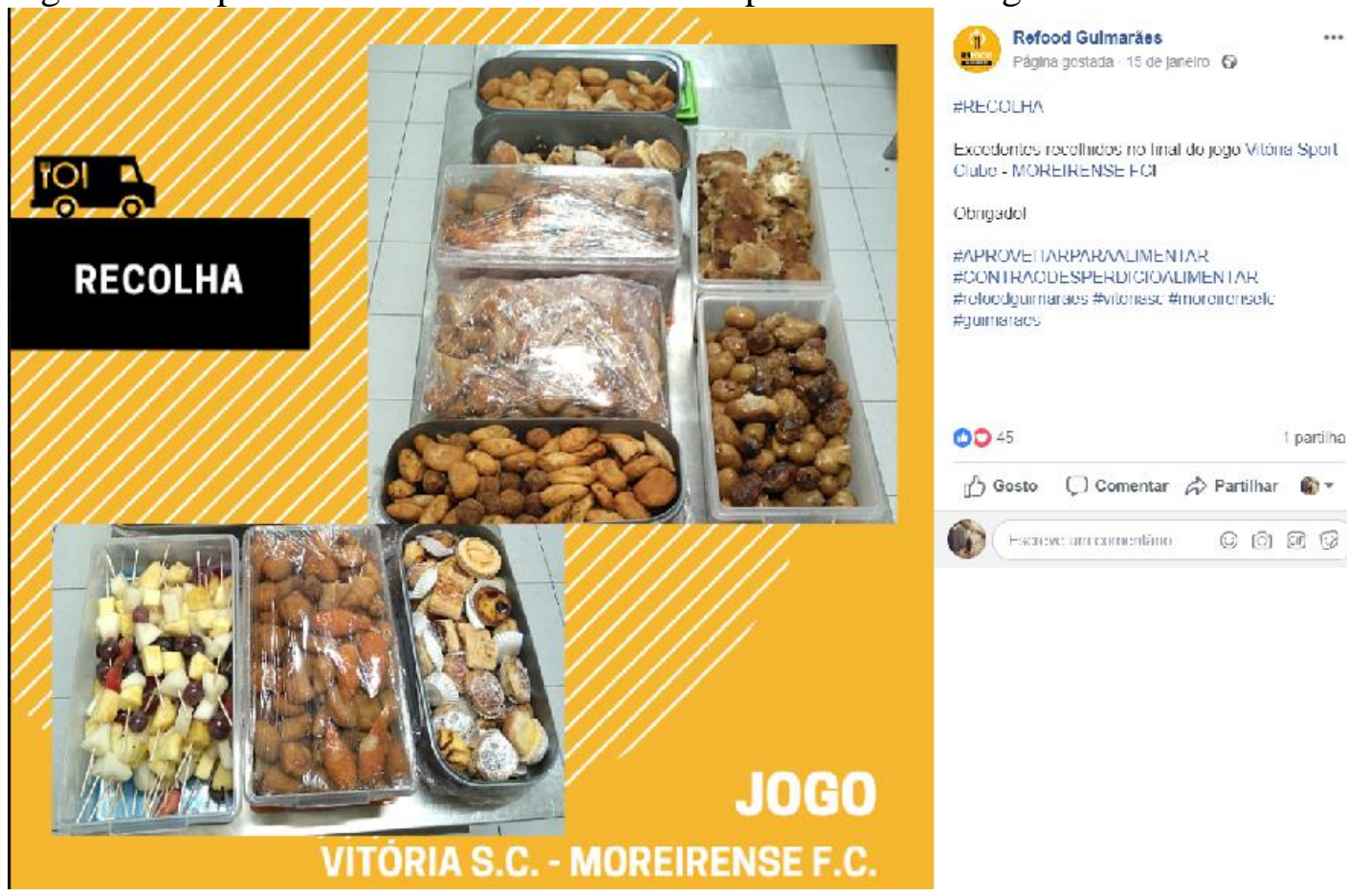

Figure 3. An appeal for volunteers (the message is: "Be one of us! Become a volunteer")

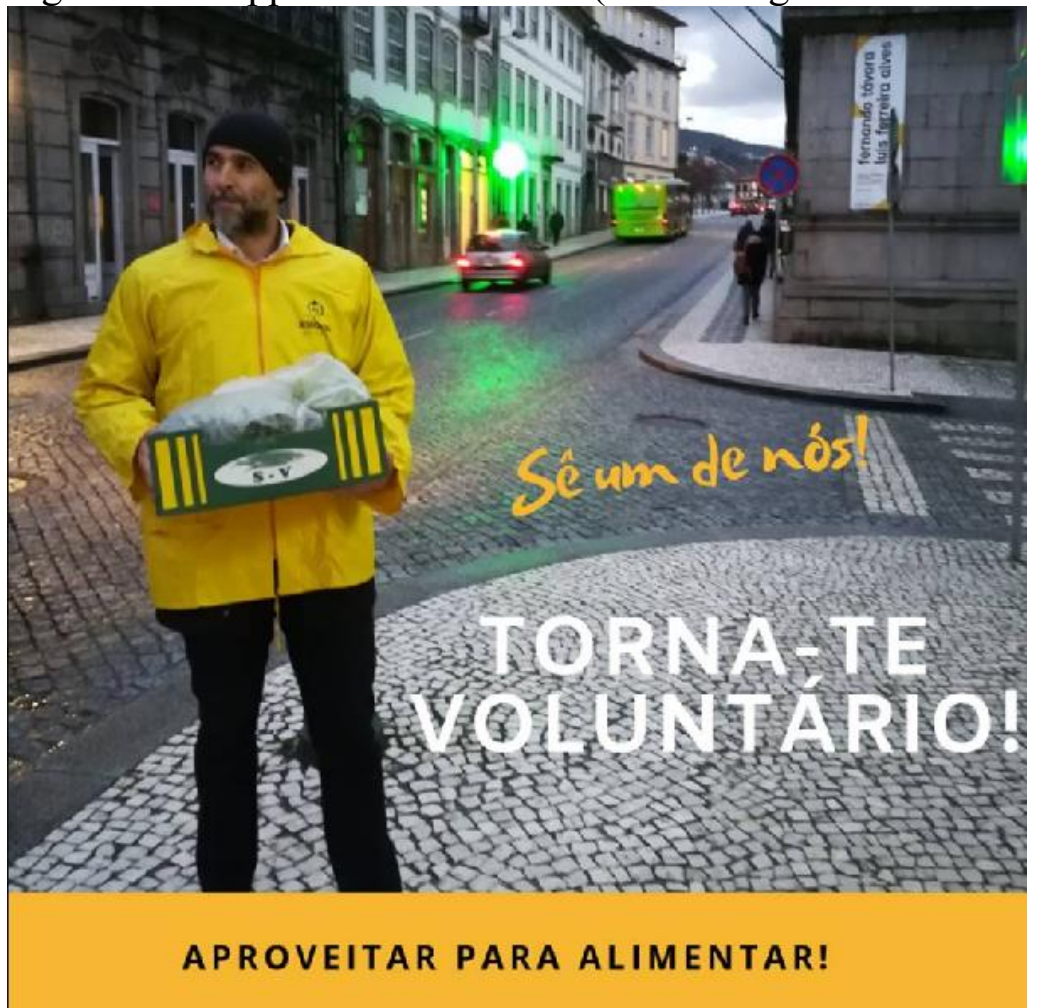


Appendix 4. Documental Analysis of Annual Report

Annual Report

\begin{tabular}{|c|c|c|c|c|}
\hline & 2011 & 2012 & 2013 & 2014 \\
\hline \multicolumn{5}{|l|}{ 1.Dimension of Economic Sustainability } \\
\hline 1.1 Current External Services & $2.436,25 €$ & $18.267,77 €$ & $21.976,76 €$ & $99.038,95 €$ \\
\hline 1.2 Staff Costs & 0 & 0 & 0 & 0 \\
\hline 1.3 Consumable Supplies & 0 & $6.144,84 €$ & $57.662,15 €$ & $206.368,89 €$ \\
\hline 1.4 Other Expenses and Losses & $4.003,56 €$ & $29,12 €$ & $294,84 €$ & $1.406,75 €$ \\
\hline 1.5 Income/Expenses & $28,55 €$ & $-24,71 €$ & $0,00 €$ & $0,00 €$ \\
\hline 1.6 Number of Beneficiaries & 50 & 140 & 482 & 1750 \\
\hline 1.7 Operating Grants and Subsidies & $6.461,52 €$ & $24.417,02 €$ & $79.933,62 €$ & $311.367,13 €$ \\
\hline \multicolumn{5}{|l|}{ 2. Dimension of Social Value Creation } \\
\hline 2.1 Number of volunteers & 1 & 100 & 704 & 2000 \\
\hline 2.2 Number of distributed meals & 12.000 & 100.000 & 150.000 & 200.000 \\
\hline 2.3 Number of nuclei (subsidiaries) & 1 & 2 & 4 & 8 \\
\hline 2.4 Number of food sources & 30 & 50 & 205 & 420 \\
\hline 2.5 Achievement of objectives & $\sqrt{ }$ & $\sqrt{ }$ & $\sqrt{ }$ & $\sqrt{ }$ \\
\hline
\end{tabular}

